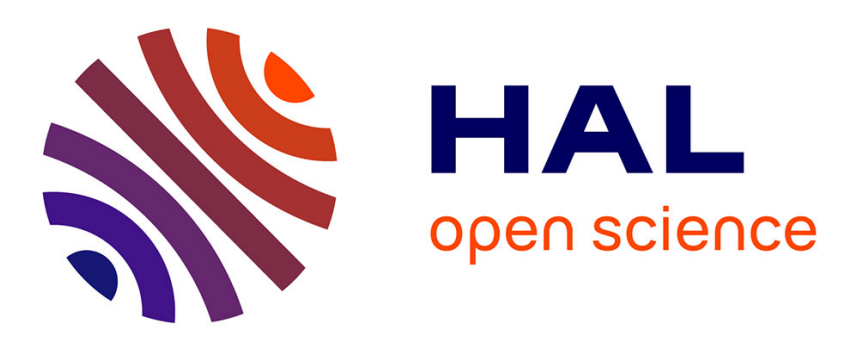

\title{
Prospects and contradictions of the electrification of the European automotive industry: the role of European Union policy
}

\author{
Tommaso Pardi
}

\section{- To cite this version:}

Tommaso Pardi. Prospects and contradictions of the electrification of the European automotive industry: the role of European Union policy. International Journal of Automotive Technology and Management, 2021, 21 (3), pp.162-179. hal-03102947

\section{HAL Id: hal-03102947 \\ https://hal.science/hal-03102947}

Submitted on 6 Jan 2022

HAL is a multi-disciplinary open access archive for the deposit and dissemination of scientific research documents, whether they are published or not. The documents may come from teaching and research institutions in France or abroad, or from public or private research centers.
L'archive ouverte pluridisciplinaire HAL, est destinée au dépôt et à la diffusion de documents scientifiques de niveau recherche, publiés ou non, émanant des établissements d'enseignement et de recherche français ou étrangers, des laboratoires publics ou privés. 


\title{
Prospects and contradictions of the electrification of the European automotive industry: the role of European Union policy
}

\section{Tommaso Pardi}

\author{
CNRS, \\ IDHES, \\ ENS-Paris-Saclay, \\ Cachan, France \\ Email: tpardi@ens-paris-saclay.fr
}

\begin{abstract}
The article analyses the role that the EU regulatory framework for the reduction of $\mathrm{CO}_{2}$ emissions in the transport sector has played during the last twenty years in moving the industry away from what it was supposed to do: reduce weight, mass and size of the cars sold to make them less polluting. It shows that the current race towards electrification can be seen as the result of this paradox. It argues that under the ongoing upmarket drift in new car sales the social, economic and political costs of electrification increase, while its environmental benefits decrease.
\end{abstract}

Keywords: electric vehicle; environmental policy; European Union; automotive industry; Gerpisa; Dieselgate.

Reference to this paper should be made as follows: Pardi, T. (2021) 'Prospects and contradictions of the electrification of the European automotive industry: the role of European Union policy', Int. J. Automotive Technology and Management, Vol. 21, No. 3, pp.162-179.

Biographical notes: Tommaso Pardi is a Senior Researcher at the CNRS (IDHES - ENS Paris-Saclay) France, and the Director of the Gerpisa network of research on the car industry. He is teaching economic sociology at the ENS Paris-Saclay. His main areas of research are economic sociology, sociology of markets, organisational studies and sociology of work with a particular focus on the automotive industry. His current projects concern industry 4.0, the EV revolution and the reorganisation and internationalisation of automotive R\&D.

\section{Introduction}

Since 1998, the European Commission (EC) has tried to reduce cars' greenhouse gas emissions by regulating average $\mathrm{CO}_{2}$ emissions of new cars: from $174 \mathrm{CO}_{2} \mathrm{~g} / \mathrm{km}$ in 1995 , to $130 \mathrm{~g}$ in 2015 , and $95 \mathrm{~g}$ in 2021 . But this policy has proved inefficient. While the total greenhouse gas emissions in the European Union have diminished by $16 \%$ between 2000 and 2017, those from the transport sector, which account for one fourth of the total emissions, have increased by 3\%. Road transport is the main culprit with cars representing $60 \%$ of total transport emissions. 
The Dieselgate scandal in 2015 revealed one of the causes of these disappointing results. Car manufacturers had optimised their cars for the laboratory test, including the use of deceit devices, to comply with the regulation, while their Real Drive Emissions were declining only marginally. After Dieselgate, the EC decided to harden its policy: it has introduced a new double homologation test in laboratory and in Real Drive conditions, increased penalties in case of non-compliance, and set a new limit of $80 \mathrm{CO}_{2}$ $\mathrm{gr} / \mathrm{km}$ for 2025 and of $60 \mathrm{CO}_{2} \mathrm{gr} / \mathrm{km}$ for 2030. The main implication of these changes is the de facto abandon of the technological neutrality previously defended by the EC. It is now clear that carmakers will need to increase the sales of electric vehicles (EVs) to comply with the 2021 and $2025 \mathrm{CO}_{2}$ targets, or face annual penalties estimated in 2019 at about 31 billions $€$ for the whole industry.

The purpose of this article is to analyse the consequences and prospects of this new policy through the prism of its own contradictions. I will argue in particular that while this new policy hardens the existing legal framework, it does not deal with the institutional causes of its previous failure. This is in the particular the case of the parameter by which the $\mathrm{CO}_{2}$ target for each carmaker is based on the average weight of the vehicles sold, meaning that if the vehicles are heavier the targets are less demanding than for lighter vehicles. This parameter, which was introduced in the European regulation in 2008 following important lobbying efforts by the German Government, was meant to protect premium brands whose models are several hundred kilos heavier than those assembled by generalist brands. However, since heavier cars are more easily compliant with the regulation and since it is also easier to introduce greening technologies in more expensive cars, these weight-based targets have pushed the whole European automotive industry upmarket. If some reports and academic papers have already stressed the 'dangers' implied by weight-based targets for the greening of the automotive industry (T\&E, 2007; Berjoza and Jurgena, 2017; Serrenho et al., 2017), I will provide in this paper an empiric analysis of how they have actually transformed the average car sold in Europe. I will also show how these changes have benefited premium carmakers, whose grip over the European market and institutions have increased during this period.

Due to the same reasons, the average car sold in Europe has also become more expensive during this period. Households found it more difficult to acquire a new car and this resulted in the aging of the car fleet that diluted and slowed down the diffusion of green technologies (Jullien and Pardi, 2011). Since electric cars are much more expensive than conventional ones (by about $€ 10,000$ ), the current policy will reinforce this trend, at least in the medium term. I will argue that electrifying conventional cars, rather than using electrification as a tool to flip the upmarket trend, is going to increase the economic and social costs of electrification, while making its environmental benefits less relevant.

For instance, the fact that generous government subsidies are available for richer households to acquire expensive electric cars, while poorer households bear the economic and social cost of holding on to old and polluting cars, is problematic. As exemplified by the recent 'yellow jackets' social movement in France, discrimination against the users of older cars (higher fuel taxes) can raise fierce political opposition against greening policies. The lack of social inclusivity in the current transition towards electrification could therefore undermine its political viability.

Furthermore, this problem has for the time being only concerned rich Western countries, where these subsidies are available, but it could become more acute in new member states in Central and Eastern Europe (CEE). As shown by the European 
Environmental Agency (EEA) data, these countries have become the main contributors to the growth of $\mathrm{CO}_{2}$ emissions in transport. Their total $\mathrm{CO}_{2}$ emissions from cars increased by $80 \%$ between 2000 and 2017 , while in the EU17 countries they decreased by $6 \%$. This is due mainly to the fact that their rate of car equipment grew much faster than in EU17 countries, but rather than buying new cars, they bought old second hand cars imported from Western European countries. It is already clear that these countries and their citizens will not be able to access the new electric cars. This problem seems also to concern Southern European countries that lag far behind in the introduction of electromobility.

Finally, and more generally, the reliance of the current regulatory framework on technology as the only mean to reduce $\mathrm{CO}_{2}$ through market-based mechanisms remains unquestioned despite the failure of this policy during the last 20 years. Indeed, rather than addressing this failure and developing a more comprehensive policy to steer the ecological transition in the transport sector, the EC keeps relying on new technologies alone - electrification, in the medium term, autonomous vehicles, in the long-term - to achieve $\mathrm{CO}_{2}$ reduction and shared mobility.

To explore these contradictions and analyse their political, social and environmental implications the article is organised as follows.

First, I will explain the race towards electrification in 2020/2021 by focusing on the impact of the 2015 Dieselgate scandal. I will show in particular how Dieselgate triggered a rapid hardening of the existing regulation for $\mathrm{CO}_{2}$ reduction in the transport sector and also provided a convenient explanation for its past failures by placing all the blame on carmakers.

Second, I will analyse in detail the upmarket drift in new car sales in Europe between 2000 and 2018. This upmarket drift, which made the average car sold in the single market heavier, bigger and more powerful, is somehow a mystery, as the industry should have moved in the exact opposite direction to reduce $\mathrm{CO}_{2}$ emissions. I will show that this trend was shaped by the EU regulation, and that the new regulations introduced after Dieselgate have not stopped but rather reinforced the upmarket drift.

Finally, I will discuss the implications of the upmarket drift for electrification, explaining why it will make its economic, social and political costs higher, and its environmental benefits lower.

\section{The impact of Dieselgate}

During the first four months of 2020, the combined market share for EVs in Europe climbed to $8 \%$ from $3 \%$ in 2019 and is expected to reach $12 \%$ by the end of the year (T\&E, 2019; ICCT, 2020). Just five years ago, in 2015, it would have been almost impossible to forecast such a fast increasing market share for EVs in Europe. The European automotive industry had successfully met the 2015 target of $130 \mathrm{CO}_{2}$ gr per km and was planning to meet the $95 \mathrm{CO}_{2}$ gr target of 2021 by increasing the market share of diesel cars, by improving internal combustion engines (ICE), and by only marginally adding EVs to their sales. At the time the market share for EVs in Europe was of less than $1 \%$.

So what happened? What triggered this fast radical transformation in an industry well know for its inertia? The answer is Dieselgate. In September 2015, Volkswagen was found guilty by the US Environmental Protection Agency of using a cheating device in the homologation tests for its diesel models in order to artificially reduce the emission 
levels of $\mathrm{CO}_{2}$ and $\mathrm{NO}_{\mathrm{x}}$. It became soon evident that the use of such devices did not concern only VW, but the whole automotive industry. While this was not really a secret amongst industry experts, regulators and environmental non-governmental organisations (NGOs), Dieselgate made the increasing gap between 'real world' emissions and 'type approval' emissions of public knowledge. On average this gap for $\mathrm{CO}_{2}$ emissions had increased in Europe from 8\% in 2000 to $40-45 \%$ in 2015 (Tietge et al., 2019). In other terms, while the industry was claiming of having reduced $\mathrm{CO}_{2}$ emissions by $30 \%$ between 2000 and 2015, in reality it had only reduced them by $10 \%$. Negotiations had already started in 2013 at the European level to introduce a new homologation test as a way to reduce this gap, but Dieselgate dramatically accelerated the whole process.

Under close scrutiny from the media, European parliament and environmental NGOs, the EC introduced in 2017 the World Harmonized Light-Duty Vehicles Test Procedure expected to reduce the gap to $20 \%$, coupled with a Real Drive Emission test expected to further reduce it to $10 \%$. New cars will be also equipped with on-board fuel consumption monitoring devices from 2021 onward to keep the gap under control. The practical implications of this hardening of the regulation have been particularly challenging for the European automotive industry at a time when it was already expected to reduce its $\mathrm{CO}_{2}$ emissions from $130 \mathrm{gr}$ in 2015 to $95 \mathrm{gr}$ in 2021.

Furthermore, a second major consequence of Dieselgate has been to disqualify the main technology that the European industry had been developing to reduce $\mathrm{CO}_{2}$ emissions: the diesel engine. Diesel cars in Europe emit on average between $15 \%$ and $25 \%$ less $\mathrm{CO}_{2}$ than gasoline cars (at the price of four times higher emissions of air pollutants) (IEA, 2019), therefore the dieselisation of new car sales was meant to reduce $\mathrm{CO}_{2}$ emissions and meet regulations. The market share of diesel cars increased from $35 \%$ in 2000 to $52 \%$ in 2015 , but since the Dieselgate it kept falling, and in 2019 was down to $30 \%$. Because of this sharp fall, the average tested $\mathrm{CO}_{2}$ emissions from new cars in Europe started to increase after more than 20 years of constant decline and was up to $122 \mathrm{~g}$ in 2019, which is $27 \mathrm{~g}$ more than the 2021 target. In case of non-compliance, the penalties for each carmaker are of $€ 95$ for each gram above the target multiplied by the total vehicles sold. The $122 \mathrm{~g}$ of 2019 would therefore generate 31 billions euros of annual penalties in 2021 .

So how can the industry achieve a $27 \mathrm{~g}$ reduction in two years, with more stringent test protocols and diesel sales falling? The only possible answer is electrification and the EC opened a door to facilitate the transition through the introduction of 'super credits' for low emission vehicles. Starting in 2020 each vehicle emitting less than $50 \mathrm{CO}_{2} \mathrm{~g}$ per $\mathrm{km}$ is counted twice for determining the average emissions for each carmaker, and only EVs fulfil this criterion. According to a report by T\&E (2019), a 12\% market share of EVs would be required at the European level to meet the $202195 \mathrm{~g}$ target, but as the super credits will stop two years later, we are looking at a minimum of $25 \%$ by 2023 , which is 8 times more than in 2019.

Dieselgate played therefore a decisive role in accelerating the electrification of the European automotive industry. But even more fundamentally it has also helped regulators, policy makers and experts to find an explanation to the failure of the past $\mathrm{CO}_{2}$ emissions policies for the transport sector in Europe. As we can see in Figure 1, the transport sector is the only major contributor to $\mathrm{CO}_{2}$ emissions whose emissions rather than diminishing have been constantly increasing since 1990, with the only exception of a short period after the 2008 financial crisis. 
Figure 1 Indexed EU GHG emissions per sector (1990-2018) (see online version for colours)

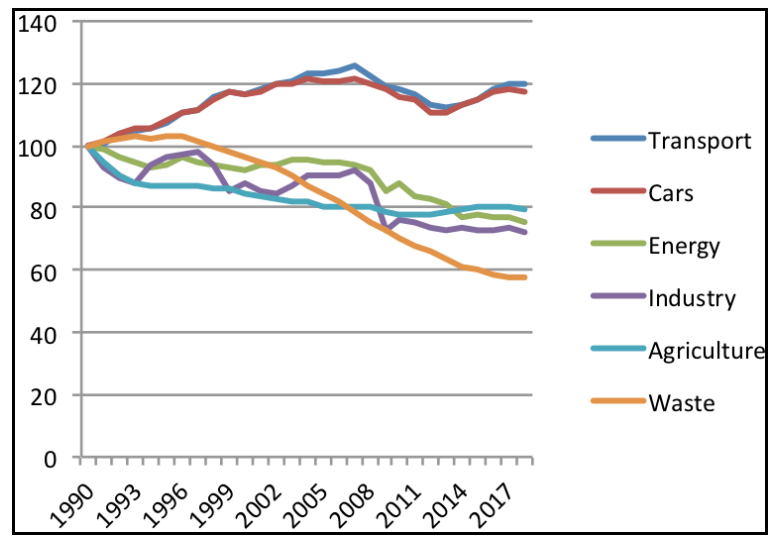

Source: EEA, author own calculation

Before Dieselgate there was no public debate about the reasons for this failure, and if solutions were searched in Brussels this was done behind the scenes. No clear consensus had emerged for explaining the failure or for changing the regulation in order to address it. These difficulties highlight how delicate the matter was and still is. The automotive industry is a strategic sector for the European economy. It is a key employer in several EU countries, the main contributor to R\&D spending, and also the biggest EU exporter. It is therefore very difficult to pass a new regulation that is not 'approved' by the industry and by the main automotive countries, and in particularly by Germany that is by far the most important and influential amongst them.

Against this background, Dieselgate provided a convenient explanation for the failure of the policy that was now needed in the public debate triggered by the scandal. This explanation consisted in blaming the carmakers. Not only they were cheating on their commitments, but they were also selling heavier and bigger cars to maximise their profitability:

"The car industry circumvents emissions regulations by all possible means - and has successfully done so for decades. [...] It is tempting to blame car-buyers for the rising $\mathrm{CO}_{2}$ but the market for SUVs has to a large extent been created by carmakers' skillful marketing and pursuit of higher profits." [T\&E, (2018), p.3, p.32]

This citation is taken from a 2018 report made by the environmental ONG Transport \& Environment, which has been influential in shaping the new EU regulation on $\mathrm{CO}_{2}$ emissions. It is interesting to note that the report does not suggest banning SUVs but forcing carmakers to both comply with the regulation and introduce more effective greening technologies:

"The first key development must be to accelerate the shift to electro-mobility [...]. Fortunately, electro-mobility is available now and the performance and cost of batteries is improving rapidly. A cost-effective solution is in sight and Europe needs to seize the opportunity to be a world leader in this emerging technology to preserve its important car industry." [T\&E, (2018), p.4, p.52]

The automotive industry has also come to agree with both the explanation and the electro-mobility solution, taking the blame for past failures and endorsing electrification 
as the way forward. What is somehow surprising in this analysis is not the fact of blaming the carmakers, whose responsibility has been clearly established, but that both the regulator and the regulation are not questioned if not for their naivety. Even in recent academic articles the blame goes to the "the lack of stringency via exploitation of flexibilities by automakers" [Skeete, (2017), p.478]. The overall design of the regulation is not brought up as a potential contributor to its own failure, and the EC is generally considered as the main actor trying to destabilise the 'automobility paradigm' while carmakers and national governments fought back to keep the 'status quo' (Hoffmann et al., 2017).

As I have argued in the introduction, the problem with this consensual view is that it does not address the institutional causes of the policy failure, and in particular how the regulation contributed to the upmarket drift in new car sales in Europe, making cars heavier and more powerful precisely at the time when one wanted the opposite to happen to reduce $\mathrm{CO}_{2}$ emissions. In the next section I will analyse how this happened and what are its causes and consequences for both carmakers and $\mathrm{CO}_{2}$ emissions.

\section{The Upmarket drift and its institutional causes}

In this section I will use the public data made available by the environmental ONG ICCT in their annual European pocketbook reports to trace the evolution of the average car sold in Europe between 2001 and 2018 by country and by brand. ${ }^{1}$

Figure 2 Indexed key performance parameters of the average car sold in EU28 (2001-2018) (see online version for colours)

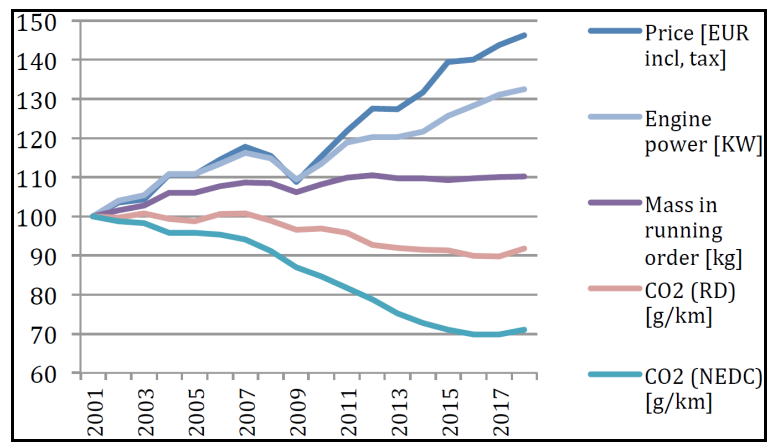

Notes: $\mathrm{RD}=$ Real Drive; NEDC $=$ New European Driving Cycle.

Source: ICCT Pocketbook, author own calculation

As we can see in Figure 2, the average car sold in Europe gained 10\% of weight ${ }^{2}$ between 2001 and 2008, which is equivalent to $129 \mathrm{~kg}$. If we go back to 1995 , when the EC first introduced the regulation to reduce $\mathrm{CO}_{2}$ emissions in the transport sector, the weight gained by the average European car amounts to $259 \mathrm{~kg}$ (20\%) (AEA, 2011). Weight is the most important factor in determining fuel consumption, and therefore $\mathrm{CO}_{2}$ emissions. A $10 \%$ weight increase is roughly equivalent to a $7 \%$ increase in $\mathrm{CO}_{2}$ emissions (ICCT, 2017). Furthermore, in order to improve the performances of these heavier vehicles, engine power was also raised (by $15 \%$ between 2000 and 2008). Engine power is another factor that has a negative impact on emissions, as the extra energy that is used to 
accelerate also increase fuel consumption: a $15 \%$ increase is equivalent to $7-10 \%$ increase in $\mathrm{CO}_{2}$ emissions (Kolke et al., 2003).

It is therefore a paradox that at the time when the automobile industry committed on a voluntary basis to reduce $\mathrm{CO}_{2}$ emissions by $25 \%$ between 1998 and 2008, carmakers made their life harder by adding so much weight and engine power to the cars they sold. Not surprisingly they failed to meet the 2008 target of $140 \mathrm{CO}_{2} \mathrm{~g} / \mathrm{km}$. As we can see in Figure 2 Real Drive $\mathrm{CO}_{2}$ emissions did not diminish between 2001 and 2008, and only diminished by $10 \%$ in the laboratory test. The extra weight and extra engine power completely offset both the progress made on engine technology and the increasing market share of diesel models (see Figure 7).

The EC introduced a new mandatory standard in 2009 of $130 \mathrm{CO}_{2} \mathrm{~g} / \mathrm{km}$ for 2015 and of $95 \mathrm{~g} / \mathrm{km}$ for 2020 with penalties in case of non-compliance. Starting from 2012 the weight of the average European car finally stabilised at around $1,400 \mathrm{~kg}$. But this was the result of a trade-off between different moving parts. On the one hand, the industry invested in lightening technologies to reduce weight: it increased for instance the share of lighter materials, such as plastic, aluminium and high strength steel; and it downsized engines (by 9\% between 2008 and 2018). On the other hand, the upmarket drift did not stop: the average European car became longer $(+9 \mathrm{~cm})$, wider $(+4 \mathrm{~cm})$ and taller $(+2 \mathrm{~cm})$ between 2008 and 2018; the share in total sales of automatic transmission and 4 wheel drive, which also add weight and $\mathrm{CO}_{2}$ emissions, grew respectively from $13 \%$ to $36 \%$ and from $9 \%$ to $14 \%$ during this period; and engine power increased by a further $15 \%$. As in the previous period, the net result of these paradoxical trends was an increasing difficulty in achieving $\mathrm{CO}_{2}$ reductions, and the industry answer consisted in using new technologies to optimise $\mathrm{CO}_{2}$ performance in the homologation test to meet the 2015 target of $130 \mathrm{CO}_{2} / \mathrm{g}$ as exemplified by the growing gap between NEDC and Real Drive $\mathrm{CO}_{2}$ emissions.

As put by Skeete (2017, p.379), “it would appear that part of OEMs' difficulty in hitting emissions targets is self-inflicted." But the question is why the industry would do that? Why would they take such a risk by going precisely in the opposite direction they were expected to take?

As we have seen before in the 2018 T\&E report, the consensual answer to this question is: because they were greedy and privileged profits over greening. The idea however that profitability in the automobile industry is correlated with upmarket strategies does not sit well with the historical understanding of this industry, in particular in Europe. The upmarket strategy is a natural one for premium brands, as they are capable of extracting value from selling more expensive cars to wealthy consumers, but not for the generalist brands that have historically dominated the European market. These brands have been rather successful in going down-market by selling smaller, lighter, cheaper cars such the Fiat Panda, the Renault Twingo, the Peugeot 205, the Opel Corsa and the Ford Fiesta, which all significantly contributed to the profitability of these carmakers in the 1980s and 1990s (Freyssenet et al., 1998).

In order to see how these different brands behaved during the upmarket drift in European sales I broke down the data in two groups: the premium group, which consists of Mercedes, BMW, Audi and Volvo, whose average car price was $€ 32,900$ in 2001; and the generalist group, which consists of Renault, Peugeot, Citroën, Fiat, Opel and Ford, whose average car price was $€ 16,500$ in 2001 . I took out from these two groups the Volkswagen brand which I consider separately because it is neither a premium brand, even if it shares all its manufacturing platforms with Audi, nor completely a generalist 
one, as its price position is significantly higher, at $€ 20,500$ in 2001 , than the brands in the generalist group.

Figure 3 Indexed mass in running order by groups of brands (2001-2018) (see online version for colours)

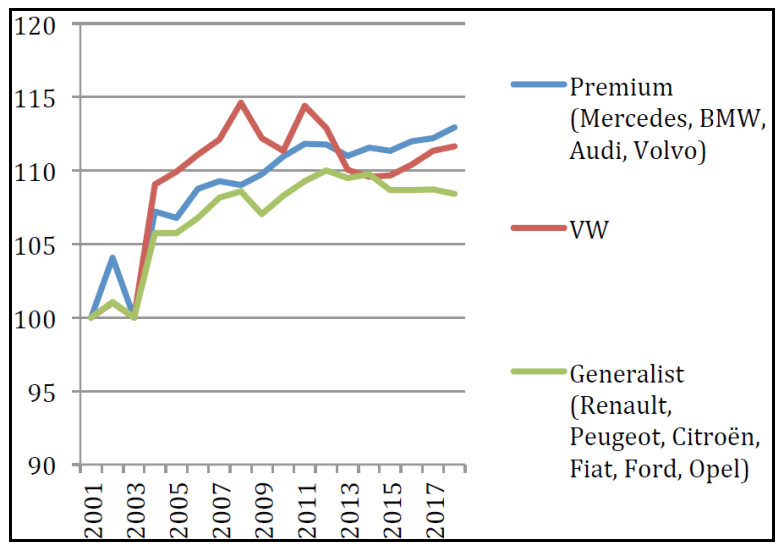

Source: ICCT Pocketbook, author own calculation

As we can see in Figure 3, the premium and the generalist groups have followed similar trends in terms of weight growth, but they started to diverge after 2014 when generalist cars became slightly lighter, while premium cars kept getting heavier. Volkswagen is the brand that increased the weight of its cars most up to 2011, and after a sharp reduction in 2012-2013 it has followed the premium path.

Figure 4 Indexed price by groups of brands (2001-2018) (see online version for colours)

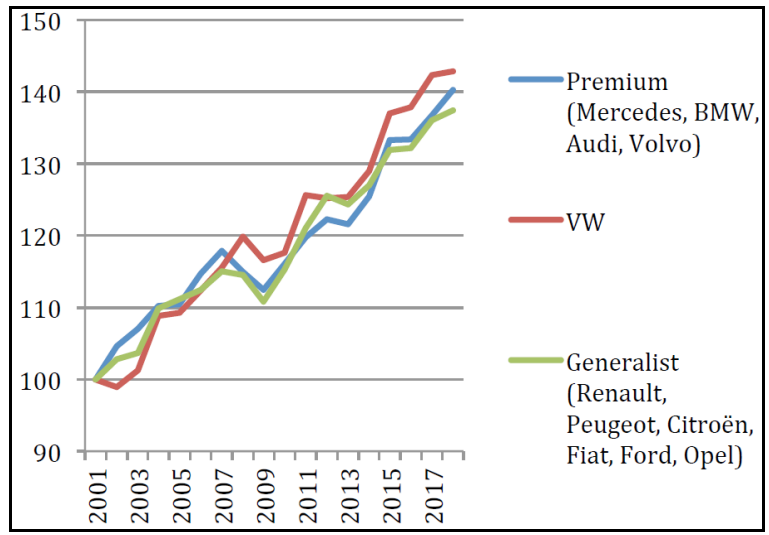

Source: ICCT Pocketbook, author own calculation

In terms of price, the trend has been exactly the same for the two groups and VW: on average the prices of new cars grew by 40\% between 2001 and 2018 (Figure 4). This common trend confirms that the upmarket drift equally concerned all European brands. Cars became more and more luxury products during this period. Households bought $60 \%$ of new cars in 2001, but this share fell to $40 \%$ in 2018, when fleet vehicles represented the majority of the European market. Furthermore, amongst households, the share of new 
cars bought by the richest quintiles by revenues constantly raised during this period (Jullien and Pardi, 2014). This increasing concentration of new car sales on a smaller and richer portion of households reinforced the upmarket drift, as the preferences of these wealthier consumers tend to go to larger and more powerful cars. Conversely, small and compact cars have also become bigger and heavier to seduce these more demanding consumers. The transformation of compact cars into SUVs corresponds precisely to this strategic shift. The hypothesis that consumer preferences alone were not at the origin of the upmarket drift can be illustrated here by the comparison with Japan. Japan has a $\mathrm{CO}_{2}$ regulation for cars that is also weight-based, but it has a specific fiscal regulation for small cars of less than $3.4 \mathrm{~m}$ of length, $1.5 \mathrm{~m}$ of width, and $660 \mathrm{cc}$ of engine displacement that makes these cars much cheaper to buy and use than larger cars. As a result their sales represent more than one third of the total Japanese market and explain why the average weight of new cars in Japan is on average $200 \mathrm{~kg}$ less than in Europe. While there is no doubt that consumer preferences play a role in the upmarket drift, regulations appear to have a more structuring and normative impact on this evolution.

To summarise, even if some differences exist between the premium and generalist groups, generalist carmakers have been playing the same upmarket game of premium brands, trying to capture fleet sales and catching up with higher margins products. Were they successful in going upmarket? Not surprisingly, as we can see from Figure 5, the answer is no. The market share of generalist brands collapsed by $30 \%$ between 2001 and 2018, while premium brands saw their sales growing by almost $40 \%$.

Figure 5 Indexed market share by groups of brands (2001-2018) (see online version for colours)

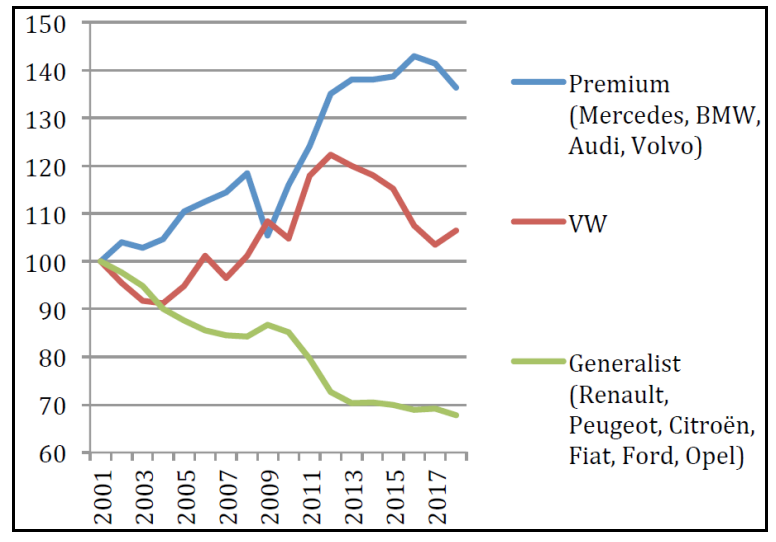

Source: ICCT Pocketbook, author own calculation

Volkswagen also saw its sales growing for most of the period, before being hit by the Dieselgate scandal in 2015. By going upmarket generalist brands did not only move away from their customer base, but they also tried to squeeze expensive premium technologies in lower margin cars. They struggled to make profits and they massively relocated production in low-cost EU countries to reduce costs (Jullien et al., 2014; Pardi, 2018). Yet, most of the generalist carmakers have almost gone bankrupt during this period and had to be rescued by their government (PSA, Fiat, Opel, Renault) and/or merged with other carmakers to survive (Opel, Fiat, PSA).

So clearly generalist carmakers did not play this losing upmarket game out of greed. So why did they play it? There are several answers to this question, ranging from cultural 
hegemony of premium brands to short-term financial pressure pushing generalist carmakers upmarket, but I will focus here on the key role of the regulatory framework. As we can see from Figure 6 not only the European market rewarded the carmakers that produce the heavier, more powerful, more expensive and more polluting cars, but it turns out that these heavier cars were also more successful in reducing their $\mathrm{CO}_{2}$ emissions, at least in the laboratory tests, than lighter cars. The gap between the average $\mathrm{CO}_{2}$ emission of the premium group and the generalist one shrank from $40 \mathrm{~g} / \mathrm{km}$ in 2001 to $16 \mathrm{~g} / \mathrm{km}$ in 2018, and this despite the fact that the average premium car gained $192 \mathrm{~kg}(+12 \%)$ against only $100 \mathrm{~kg}(+8 \%)$ for the average generalist car. How is this possible?

Figure $6 \mathrm{CO}_{2}$ NEDC* emissions by groups of brands (2001-2018) (see online version for colours)

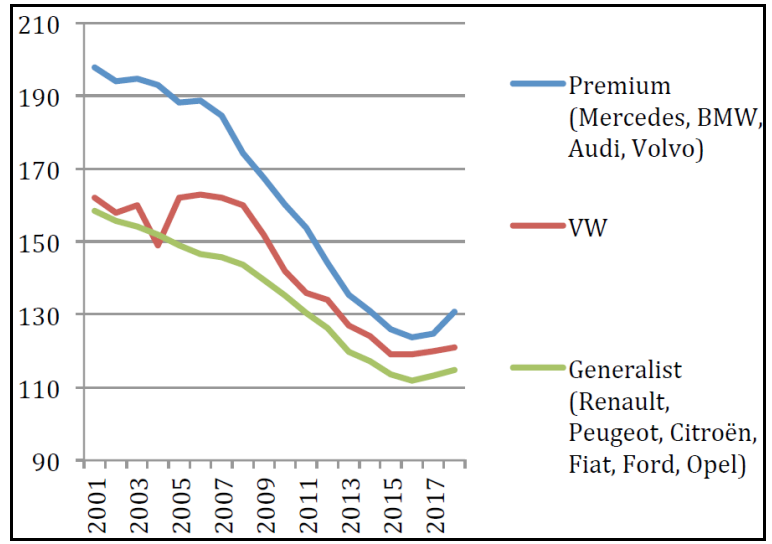

Note: *New European Driving Cycle.

Source: ICCT Pocketbook, author own calculation

The answer is threefold. First, the mandatory targets set by the 2009 regulation are weight-based, meaning that carmakers that sell heavier cars have easier $\mathrm{CO}_{2}$ targets. For 2021 the premium group will be compliant with the regulation if it reaches $102 \mathrm{CO}_{2}$ $\mathrm{g} / \mathrm{km}$, while the generalist group will have to reach $92 \mathrm{CO}_{2} \mathrm{~g} / \mathrm{km}$. This means that carmakers that increase the weight of their cars are not penalised, as their target becomes less demanding, and even more important that carmakers that reduce the weight of their cars are not rewarded, as their target becomes more demanding. This is why the regulation pushes all the carmakers, including the generalist ones, upmarket.

Second, as weight reduction is not a solution to reach the $\mathrm{CO}_{2}$ target, carmakers can only rely on greening technologies to do so, and greening technologies are expensive and more easily introduced in premium cars. During the period analysed the two main technologies to reduce $\mathrm{CO}_{2}$ emissions were diesel engines and gasoline direct injection (GDI), which are both premium technologies. In the European market the average premium to buy a diesel vehicle compared to a similar gasoline one is between $9 \%$ and $21 \%$ [IEA, (2019), p.46]. As we can see in Figure 7 the premium group has been very successful in selling diesel cars, which represented almost $80 \%$ of their sales before Dieselgate, against only $50 \%$ for the generalist group.

The gap between the two groups is even more important for GDI, a technology that can reduce $\mathrm{CO}_{2}$ emissions up to $14 \%$. As we can see in Figure 8, for most of the period 
analysed GDI exclusively equipped premium cars (including VW) and it only started to diffuse in the generalist group in the 2010s. In $201892 \%$ of premium cars were equipped with this technology against $43 \%$ of generalist cars.

Figure 7 Diesel market share by groups of brands (2001-2018) (see online version for colours)

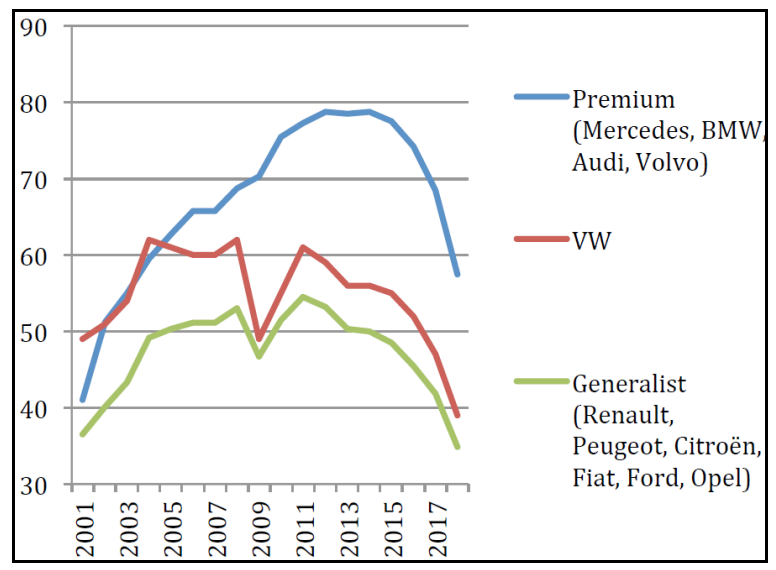

Source: ICCT Pocketbook, author own calculation

Figure 8 GDI market share by groups of brands (2001-2018) (see online version for colours)

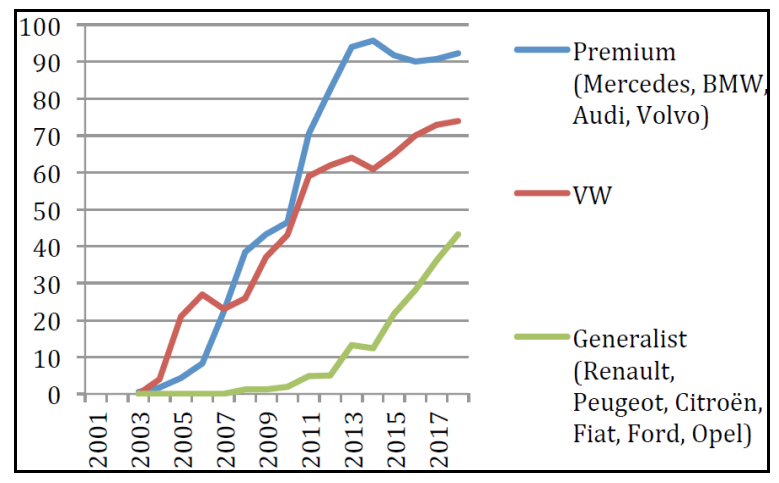

Source: ICCT Pocketbook, author own calculation

Third, besides the fact that these, as well as many other new technologies commonly found in premium models - stop-start, cylinder deactivation, etc. help in reducing $\mathrm{CO}_{2}$ emissions, they also provide new opportunities to optimise laboratory tests. For instance, in 2017 the gap between laboratories test and real world conditions was on average of $35 \%$ for gasoline cars, $41 \%$ for diesel cars, $47 \%$ for hybrid electric cars, and $221-225 \%$ for plug-in-hybrid electric cars; for manual transmission cars the gap was of $33 \%$, and of $40 \%$ for automatic transmission cars (again a premium technology); and for the premium group the gap was on average of $46 \%$, against $37 \%$ for the generalist group [Tietge et al., (2019), pp.8-13, p.33].

The electric car is also a premium technology: it has a premium to buy of around $€ 10,000-€ 15,000$, which makes it much easier to electrify premium models, and when an $\mathrm{EV}$ is equipped with large and powerful batteries it delivers fantastic acceleration and top 
speed with very low noise. Not surprisingly, even if premium brands were initially reluctant to electrify their models, as soon as they realised that diesel technology would not be enough to reach the $2021 \mathrm{CO}_{2}$ target, they rapidly forged ahead in the race towards electrification. As we can see in Figure 9, their joint market share for EVs in the first four months of 2020 was of $19 \%$, against $5 \%$ for generalist brands, confirming the bias of the European regulatory framework in favour of premium brands and their greening strategies.

There is also no doubt that the success of Tesla, the Silicon Valley's-based start-up, in reframing electrification as a premium technology, has accelerated the conversion of premium brands towards EVs. Not only because Tesla has proved that the combination of huge batteries, digital technologies and luxury features would appeal to wealthy consumers, but also because it started to take significant market share from premium brands as early as 2018 .

Figure 9 EVs market share by groups of brands (2001-2020*) (see online version for colours)

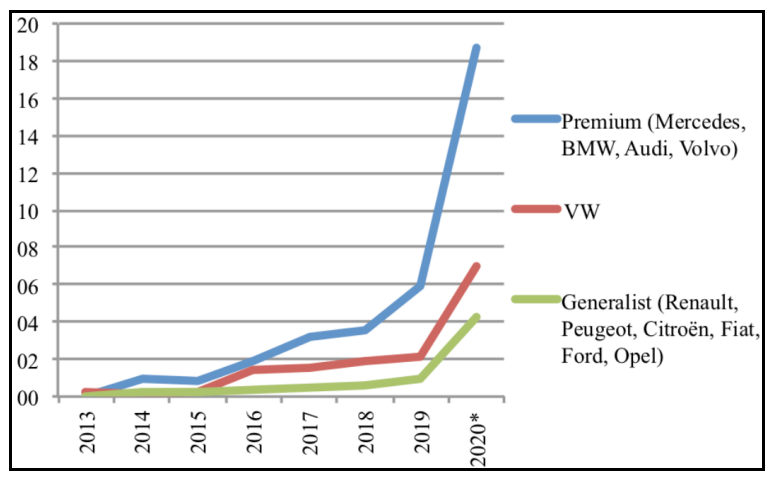

Note: *January-April 2020.

Source: ICCT Pocketbook, author own calculation

However, as we will see in the next section, the electric car could also be a low cost technology, but this would imply to use small batteries, equipping much lighter and smaller vehicles, which would be driven for specific dedicated mobility purposes and not as conventional multipurpose vehicles. This was for example the case of the successful low-speed vehicles in China (Wang and Kimble, 2011). But this is not the road taken by the European automobile industry that keeps going upmarket, and electrification will not change the upmarket drift, it will probably make it worse.

\section{The environmental, economic and political costs of upmarket electrification}

Ten years ago when the automotive industry started to consider mass production of EVs and some brands launched their first electric models in the market, it was generally understood that EVs could not be conventional cars due to their limited range and long recharging time (Jullien and Pardi, 2013). Which is why the transition towards EVs was expected to transform the automotive paradigm from personal owned mobility to shared mobility, from multipurpose vehicles to dedicated vehicles based on service business 
models and requiring a dense network of charging stations (Villareal, 2011; Fojcik and Proff, 2014; Hildermeier, 2016). One of the first electric cars to embody these characteristics was the Bolloré Bluecar used by the Autolib car-sharing service in Paris (Vervaeke and Calabrese, 2015). The Bluecar was an anti-premium model: extremely small and compact ( $3.3 \mathrm{~m}$ vs. the $4.2 \mathrm{~m}$ of the average EU car in 2009), with no painting and basic interiors, weighing $1,070 \mathrm{~kg}$, including the $300 \mathrm{~kg}$ of the $30 \mathrm{kw}$ battery, with a top speed of $120 \mathrm{~km} / \mathrm{h}$ and an official autonomy of $250 \mathrm{~km}$. By comparison, the Tesla model 3, which is the best sold EV in Europe during the first months of 2020, weighs between $540 \mathrm{~kg}$ and $790 \mathrm{~kg}$ more than the Bluecar, it is also $1.4 \mathrm{~m}$ longer, equipped with batteries of $54 \mathrm{kw}$ up to $77 \mathrm{kw}$ with an autonomy between 400 and $560 \mathrm{~km}$, and a top speed between 225 and $260 \mathrm{~km} / \mathrm{h}$. Between these two extremes, the evolution of the Renault Zoe, launched in 2013 as a relatively affordable car, highlights the upmarket drift of EVs in Europe. Between 2012 and 2019 its battery power more than doubled, from $22 \mathrm{kw}$ to $55 \mathrm{kw}$, its autonomy grew from $200 \mathrm{~km}$ to $400 \mathrm{~km}$, its engine power increased from $65 \mathrm{kw}$ to $80 \mathrm{kw}$, its acceleration improved by $18 \%$, the vehicle gained $75 \mathrm{~kg}$ of weight, and its price increased by $16 \%$ (against only $4 \%$ for a comparable Clio model). In other terms, rather than using technological progress in batteries and electric powertrains to make the Zoe lighter and more affordable, Renault followed the upmarket trend to improve its performance. Because of this generalised trend, it is already clear that the average European EVs will be much heavier and powerful than equivalent ICE cars. In 2017, according to IEA data the average BEV and PHEV sold in Europe were respectively $200 \mathrm{~kg}$ and $420 \mathrm{~kg}$ heavier than the average ICE car, and in the case of more recent models, like the Volkswagen E-Golf, it is on average $400 \mathrm{~kg}$ that were added to the equivalent ICE version [IEA, (2019), pp.53-54].

By contrast, the same data for the average BEV in China, which weights $210 \mathrm{~kg}$ less than an equivalent Chinese ICE car and $300 \mathrm{~kg}$ less than the average European BEV, shows that a different path is possible. One in which EVs are conceived as different products than conventional ICE cars by combining electrification, weight reduction and lower prices to provide affordable green means of transport for urban middle-classes. If the sales of EVs in China at the end of 2020 show that even here the Tesla model 3 was successful amongst wealthy consumers, the most sold EV model at the end of the year was one of the lightest, cheapest and most compact cars of the market, the Hongguang Mini produced by the SAIC - GM - Wuling joint venture, which has a basic range of 120 $\mathrm{km}$ and a top speed of $100 \mathrm{~km} / \mathrm{h}$, weighs only $700 \mathrm{~kg}$ and is sold at less than $€ 5,000$.

Now, one could argue that even if such a path would be more virtuous than the path taken by the European automobile industry, the fact that carmakers are finally electrifying their offer and taking responsibility for their environmental impact is already a progress, and that letting them selling heavier and more powerful cars is after all a reasonable price to pay for it. I would like here to highlight the reasons why I do not agree with such a view. I will start with the negative impact of the upmarket trend in EVs on environmental benefits, before focusing on its economic, social and political costs.

\subsection{Environmental impacts of heavier EVS}

For EVs, even more than for ICE cars, weight is a decisive factor. Heavier EVs require either larger batteries, which are the most expensive component of an EV $(30 \%-45 \%$ of the total cost), or deliver less autonomy, which is the most important handicap of an EV. Weight also impacts performance as it reduces acceleration and top speed and weakens 
breaking capacity. The upmarket trend means that not only the weight of the average EV is increasing, but also all its other performance parameters are improving, with more acceleration, more top speed and more autonomy, requiring larger and larger batteries, which further add weight to the car. For instance the $85 \mathrm{~kW}$ battery of a Tesla model S weighed in $2017544 \mathrm{~kg}$ for a total car weight of $2,188 \mathrm{~kg}$ (25\% of the total weight), while the $22 \mathrm{~kW}$ battery of a Renault Zoe weighed $235 \mathrm{~kg}$ for a total car weight of 1,470 $\mathrm{kg}$ (16\% of the total weight) [Berjoza and Jurgena, (2017), p.1389].

Now doubling the average size of an EV battery has negative consequences for all its life cycle. First, some of the materials needed to manufacture batteries, in particular cobalt and lithium, are rare and their extraction is polluting. By doubling the size of the average EV battery the upmarket trend will likely increase the prices of these materials and could undermine the economic viability of batteries in car production (Jetin, 2020).

Second, battery production requires a lot of energy, and since it is mainly carried out in countries where energy production has high $\mathrm{CO}_{2}$ intensity, like $\mathrm{China}^{3}$, it is extremely polluting. This is why EVs have a $\mathrm{CO}_{2}$ debt when they start to be used and it takes several years before they emit less $\mathrm{CO}_{2}$ than equivalent ICE cars. For instance, in 2018 a Tesla $\mathrm{S}$ manufactured in the US comes with a debt of 10 tons of $\mathrm{CO}_{2}$ by comparison with an equivalent Toyota Camry, and it takes on average $64,200 \mathrm{~km}$ before it pays off its $\mathrm{CO}_{2}$ debt. For a Tesla $\mathrm{S}$ manufactured and used in China, the debt grows to 15 tons of $\mathrm{CO}_{2}$, and it takes 139,400 km to pay it off. For a Renault Zoe manufactured and used in France the debt is of $2,100 \mathrm{~kg}$ of $\mathrm{CO}_{2}$ by comparison with an equivalent Renault Clio, and it takes only 16,800 km to pay it off [Arval, (2019), pp.67-86].

Third, while EVs do not emit $\mathrm{CO}_{2}$, they use energy whose production emits $\mathrm{CO}_{2}$. In 2018 the EU energy sector emitted 3.3 billion tons of greenhouse gases, which is much less than the 4.3 billion tons emitted in 1990, but which is still more than the 0.9 billion tons emitted by the transport sector in 2018. Doubling the size of the battery to carry much heavier vehicles can amount to doubling the amount of energy used by EVs and therefore their related $\mathrm{CO}_{2}$ emissions: for instance a Renault Zoe with a $290 \mathrm{~kg}$ battery $(22 \mathrm{~kW}$ ) (total weight of $1,470 \mathrm{~kg}$ ) consumes on average $94 \mathrm{Wh} / \mathrm{Km}$ while a Tesla model $\mathrm{S}$ with a $540 \mathrm{~kg}$ battery $(85 \mathrm{~kW}$ ) (total weight of 2,188 kg) consumes $200 \mathrm{Wh} / \mathrm{Km}$ [Berjoza and Jurgena, (2017), p.1391].

Finally, cars generate harmful fine particles (PM2.5 and PM10) mainly through brake, tyre and road wear (60\% of total emissions), and this does not change with EVs (AQEG, 2019). Extra weight increases wearing further contributing to air pollution. Also bigger cars take more place increasing urban congestion that also raises emissions from transport.

\subsection{Economic and social impacts of heavier EVS}

The upmarket trend on electrification will make the average European EV more expensive, slowing down its diffusion. For the time being, EVs are only sold in high revenues countries, mainly in the North of Europe, and only when generous state subsidies are available (on average between $€ 5,000$ and $€ 10,000$ ). We have already seen how much the upmarket drift has benefited premium brands, whose production is mainly located in Germany, and how much it has harmed generalist brands in France and Italy. Electrification is likely to reinforce this trend by making harder for generalist brands to break even, leading to further restructuring and relocation of production towards low-wages countries and raising further problems concerning the social and political 
sustainability of such a transition. Furthermore, due to the fact that the production of EVs requires less workers in manufacturing (20-25\%), massive generalised restructuring has also been announced for the fist time in Germany.

The high price of new EVs means that for the time being their access is restricted to wealthy households, who often benefit from generous State subsidies, fiscal advantages, free public parking, free access to city centres, preferential road lanes, and lower usage cost due to low energy and maintenance cost. By contrast, the poorer households that often must use a car to go to work, bring the children to school and buy groceries (Demoli, 2015) have to bear the economic and social costs of holding on to aging ICE cars. Governments are in fact tempted to recover both the rising cost of electrification and the declining revenues from fuel taxes through car usage fees including higher fuel taxes. We have seen in the case of France how controversial such policies can be. The 2018 increase of fuel taxes justified on environmental terms triggered the largest social movement since 1968 known as the yellow jackets movement. In a European context marked by growing politically instability and the progression of populist parties, it would not be surprising if this increasing social divide in the access to sustainable mobility will further trigger social unrest and class struggle.

Figure 10 Greenhouse gases from fuel combustion in cars (thousand of tonnes) 1990-2018 (see online version for colours)

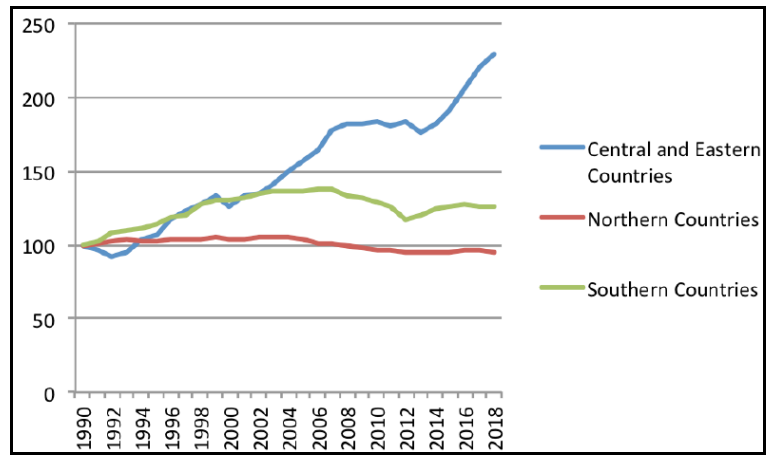

Source: EEA, author own calculation

While it is reasonable to expect that in the long run expensive EVs will turn into affordable second hand cars, one should keep in mind that even in a high wage country like France the average second hand car bought by the average French household is 9 years old and costs less than $€ 4,000$ (source: autoways). This means that it will take much more than a decade before the average EV model currently sold in the European market will become accessible to the average European household, even in high wage countries, and therefore much longer for poorer households.

Finally, the most important contributors to the growth of $\mathrm{CO}_{2}$ emissions in road transport are CEE countries (see Figure 9). Their greenhouse gases emissions from cars have increased by $130 \%$ between 1990 and 2018. This is due both to the fast growth of their car fleets, and to the fact that this growth has been mainly achieved by importing old second hand cars from EU17 countries. In Poland for instance, between 2004 and 2012 7.4 million second hand cars have been imported and during the same period only 2.5 million new cars have been sold. As a result the share of cars older than 10 years in the total fleet has grown from $56 \%$ to $74 \%$, and those older than 20 years from $23 \%$ to $28 \%$ 
(Pardi, 2018). Besides the deregulation of the second hand cars' imports imposed by the EC between 2004 and 2009, the upmarket trend in new car sales has also contributed in killing the market for new cars of these countries that has stagnated at around 1 million units since 2000, while expected to reach 4 million units by 2020 (Pardi, 2018).

As electrification will make new cars more expensive, it is clear that under the current regulatory framework the 120 million citizens living in these countries will not be included in the new EU Green Deal. The divide between rich and poor European countries, as well as between rich and poor households, will increase and the economic, social but also environmental costs of electrification might simply prove too high for being politically sustainable.

\section{Conclusions}

The article shows the central role that the EU regulatory framework for the reductions of $\mathrm{CO}_{2}$ emissions in the transport sector has played during the last twenty years in moving the industry away from what it was supposed to do: reduce the weight, mass and size of the cars sold in order to make them less polluting. To a certain degree both Dieselgate and the current race towards electrification can be seen as the result of this paradox. Under this upmarket drift the social and economic costs of electrification increase, while its environmental benefits decrease. Such a trend jeopardises the political sustainability of the electric transition.

The purpose of this article was not to explore alternative policies, but some recommendations can be deduced from its conclusion.

The first and the most evident recommendation is to substitute weight-based targets with footprint-based targets as the latter would not penalise weight reduction while still accounting for the 'utility' of the car. However, size reduction should be also pursued as a desirable objective to reduce urban congestion and improve environmental performance. In other words, the regulation should push carmakers to reduce the weight and the size of their cars, and not the contrary!

The second recommendation is to allow for adjustments of the European regulations at the national level. The current regulatory framework corresponds to the purchasing power and state' wealth of Northern European Countries, but it is at odds with the fleet structures and mobility needs of Southern and CEE countries. Either the regulation needs to take into account these needs, as well as the problem of massive second-hand car imports in CEE countries, or it should relinquish some degree of control over market regulations to national governments.

The third and final recommendation is that the transition towards carbon free transports cannot be left to technological roadmaps and market coordination alone as highlighted by the past failure of this regulatory approach. It requires a comprehensive policy that the EC does not seem to be able to conceive, and that national governments are not able to pursue anymore (Eder and Schneider, 2018). While there is no simple solution to this problem, at least some degree of coordination must be achieved at the EU level between transport, environmental, industrial, labour and trade policies (Pichler et al., 2021) in order to steer the electrification of the automotive industry on a more efficient, green and socially inclusive track. 


\section{References}

AEA (2011) Annex - Effect of Regulations and Standards on Vehicle Prices, Final Report to the European Commission - DG Climate Action No. 070307/2010/570520/SER/A4, Brussels.

AQEG (2019) Non-Exhaust Emissions from Road Traffic, Department for Environment, Food and Rural Affairs, Scottish Government; Welsh Government and Department of the Environment in Northern Ireland.

Arval (2019) Le Véhicule Électrique est-il si Vertueux?, Arval and Eurogroup Consulting, Ruel-Malmaison.

Berjoza, D. and Jurgena, I. (2017) 'Influence of batteries weight on electric automobile performance', in Engineering for Rural Development, Vol. 16, pp.1388-1394.

Demoli, Y. (2015) 'The social stratification of the costs of motoring in France (1984-2006)', International Journal of Automotive Technology and Management, Vol. 15, No. 3, pp.311-328.

Eder, J. and Schneider, E. (2018) 'Progressive industrial policy - a remedy for Europe', Journal für Entwicklungspolitik, Vol. 34, Nos. 3/4, pp.108-142.

Fojcik, T.M. and Proff, H. (2014) 'Accelerating market diffusion of battery electric vehicles through alternative mobility concepts', International Journal of Automotive Technology and Management, Vol. 14, Nos. 3/4. pp.347-368.

Freyssenet, M., Mair, A., Shimizu, K. and Volpato, G. (1998) One Best Way? Trajectories and Industrial Models of the World's Automobile Producers, Oxford University Press, Oxford.

Hildermeier, J. (2016) 'Which role should the electric car play in Europe's cities? An analysis of publicly funded demonstration projects 2007-2013', International Journal of Automotive Technology and Management, Vol. 16, No. 1, pp.90-107.

Hoffmann, S., Weyer, J. and Longen, J. (2017) 'Discontinuation of the automobility regime? An integrated approach to multi-level governance', Transportation Research Part A: Policy and Practice, Vol. 103, pp.391-408, https://doi.org/10.1016/j.tra.2017.06.016.

ICCT (2017) Lightweighting Technology Developments, Technical Brief No. 6, ICCT.

ICCT (2020) European Passenger Car Registrations: January-April 2020, Market Monitor, ICCT.

IEA (2019) Fuel Economy in Major Car Markets, International Energy Agency.

Jetin, B. (2020) 'Who will control the electric vehicle market?', International Journal of Automotive Technology and Management, Vol. 20, pp.156-177, http://revel.unice.fr/eriep/ index.html?id=3260.

Jullien, B. and Pardi, T. (2011) 'In the name of consumer: the social construction of innovation in the European automobile industry and its political consequences', European Review of Industrial Economics and Policy, Vol. 3, No. 2.

Jullien, B. and Pardi, T. (2013) 'Structuring new automotive industries, restructuring old automotive industries and the new geopolitics of the global automotive sector', International Journal of Automotive Technology and Management, Vol. 13, No. 2, pp.96-113.

Jullien, B. and Pardi, T. (2014) 'Le postfordisme comme mythe et idéologie de la sociologie économique. Du consommateur à la construction sociale du marché automobile', L'homme et la Société, pp.193-194.

Jullien, B., Pardi, T. and Ramirez, S. (2014) 'The EU's government of automobiles: from 'harmonization' to deep incompleteness', in Jullien, B. and Smith, A. (Eds.): The EU's Government of Industries: Omnipresent, Incomplete and Depoliticized, Routledge, New York.

Kolke, R., Jäcker, M., Rauterberg-Wulff, M., Verron, H., Zimmer, W., Ostermeier, A., Stinshof, K. and Pech, C. (2003) 'CO $\mathrm{CO}_{2}$-Minderung im Verkehr', Ein Sachstands-bericht des Umweltbundesamtes, UBA, Berlin.

Pardi, T. (2018) 'Une voiture low-cost pour les pays riches: Logan et l'intégration européenne', La Nouvelle Revue du Travail, No. 12. 
Pichler, M., Krenmayr, N., Schneider, E. and Brand, U. (2021) 'EU industrial policy: between modernization and transformation of the automotive industry', Environmental Innovation and Societal Transitions, Vol. 38, pp.140-152, https://doi.org/10.1016/j.eist.2020.12.002.

Serrenho, A.C., Norman, J.B. and Allwood, J.M. (2017) 'The impact of reducing car weight on global emissions: the future fleet in Great Britain', Philosophical Transactions of the Royal Society A: Mathematical, Physical and Engineering Sciences, Vol. 375, No. 2095, pp.1-16.

Skeete, J-P. (2017) 'Examining the role of policy design and policy interaction in EU automotive emissions performance gaps', Energy Policy, Vol. 104, pp.373-381, https://doi.org/10.1016/ j.enpol.2017.02.018.

T\&E (2007) Danger Ahead. Why Weight-based $\mathrm{CO}_{2}$ Standards will make Europe's Car Fleet Dirtier and Less Safe, European Federation for Transport and Environment, Brussels.

T\&E (2018) $\mathrm{CO}_{2}$ Emissions from Cars: The Facts, European Federation for Transport and Environment AISBL.

T\&E (2019) Mission Possible: How Car Makers Can Reach their $2021 \mathrm{CO}_{2}$ Targets and Avoid Fines, European Federation for Transport and Environment AISBL, Brussels.

Tietge, U., Diaz, S., Mock, P., Bandivadekar, A., Dornoff, J. and Ligterink, N. (2019) From Laboratory to Road. A 2018 Update of Official and 'Real-World' Fuel Consumption and $\mathrm{CO}_{2}$ Values for Passenger Cars in Europe, White Paper, TNO \& ICCT.

Vervaeke, M. and Calabrese, G. (2015) 'Prospective design in the automotive sector and the trajectory of the Bluecar project: an electric car sharing system', International Journal of Vehicle Design, Vol. 68, No. 4, pp.245-264.

Villareal, A. (2011) 'The social construction of the market for electric cars in France: politics coming to the aid of economics', International Journal of Automotive Technology and Management, Vol. 11, No. 4, pp.326-339.

Wang, H. and Kimble, C. (2011) 'Leapfrogging to electric vehicles: patterns and scenarios for China's automobile industry', International Journal of Automotive Technology and Management, Vol. 11, No. 4, pp.312-325.

\section{Notes}

1 I have extracted this data with the Tabula software and created a database detailing 27 parameters of the average car sold in 20 countries or group of countries (EU28, EU13) and by 19 brands between 2000 and 2018 .

2 Weight is measured here as mass in running order: this is a mass of a vehicle including the driver (75 kg), fuel (90\% filled), liquids (cooling) and standard equipment.

3 EU production of batteries is almost non-existent, but it is planned to take place in high $\mathrm{CO}_{2}$ intensity energy countries such as Hungary, Poland and Germany, with the major exception of the investment of NorthVolt in Northern Sweden, whose 32 GWh factory is expected to start production in 2022 . 